\title{
PENINGKATAN AKTIVITAS DAN PROSES KETERAMPILAN MEMBACA INTENSIF DENGAN STRATEGI PREVIEW, QUESTION, READ, SELF-RECITATION, TEST (PQRST)
}

\author{
Elvina \\ PGSD STKIP Rokania \\ Alamat e-mail : elvinazulkarnain88@gmail.com
}

\begin{abstract}
Activities and process skills intensive reading class VI students of SDN 029 Sungaipinang still low, it is seen that the students have not been able to read intensively so that the difficulties in determining the basic idea of each paragraph and the main idea of the story. This is due to the habit of reading inefficient. The research objective to increase activity and process intensive reading skills using $P Q R S T$ strategy. This type of research is a classroom action research conducted in twocycles. Each cycle consists of four stages: planning, action, observation, and reflection. The subjects were students of sixth grade students with a number of 15 people. Data were obtained through observation sheets, field notes and student worksheets. The collected data were analyzed qualitatively. The results of the analysis of data on the first and second cycle shows that the activity and the process of intensive reading skills of students increased. At the first meeting of the first cycle phase prabaca aspects that are predicting the contents of the report gained 70.83 and made a key question learners acquire 66.66. While at the current stage of reading aspects that are answered questions acquire 71.66 and write the main facts learners acquire 63.33. At the second meeting of the first cycle phase pascabaca aspects that are written summary based on reports received 65 text and revise the summary based on the text of learners acquire 63.33. At the first meeting of the second cycle stage prabaca aspects that predict the contents of the report is the result of 72.5 and making key questions learners get the results $70 \%$. Read the current stage aspects that are answering questions and write the results of placement 70.83 main facts learners acquire 70.83. At the second meeting of the assessed aspects pascabaca stage is to write a summary based on the text of the report the results of placement 74.16 and revise writing text summaries based learners acquire 73.33. Based on the results concluded that the use of PQRST strategy can improve the activity and the process of reading skills of sixth grade students of SDN 029 Sungaipinang.
\end{abstract}

Keywords: Activities, Process, Intensive Reading, PQRST

\section{ABSTRAK}

Kegiatan dan keterampilan proses membaca intensif siswa kelas VI SDN 029 Sungaipinang masih rendah, terlihat bahwa siswa belum dapat membaca secara intensif sehingga kesulitan dalam menentukan ide dasar masing-masing paragraf dan gagasan utama cerita. Ini karena kebiasaan membaca yang tidak efisien. Tujuan penelitian untuk meningkatkan aktivitas dan keterampilan membaca intensif proses menggunakan strategi PQRST. Jenis penelitian ini adalah penelitian tindakan kelas yang dilakukan dalam dua siklus. Setiap siklus terdiri dari 
empat tahap: perencanaan, tindakan, observasi, dan refleksi. Subjek penelitian adalah siswa kelas enam dengan jumlah 15 orang. Data diperoleh melalui lembar observasi, catatan lapangan dan lembar kerja siswa. Data yang terkumpul dianalisis secara kualitatif. Hasil analisis data pada siklus pertama dan kedua menunjukkan bahwa aktivitas dan proses keterampilan membaca intensif siswa meningkat. Pada pertemuan pertama dari aspek prabaca fase siklus pertama yang memprediksi isi laporan yang diperoleh 70,83 dan membuat pertanyaan kunci peserta didik memperoleh 66,66. Sedangkan pada tahap saat membaca aspek yang dijawab pertanyaan memperoleh 71,66 dan menulis fakta utama peserta didik memperoleh 63,33. Pada pertemuan kedua siklus fase pertama aspek pascabaca yang ditulis ringkasan berdasarkan laporan menerima 65 teks dan merevisi ringkasan berdasarkan teks peserta didik memperoleh 63,33. Pada pertemuan pertama tahap prabaca tahap siklus kedua yang memprediksi isi laporan adalah hasil 72,5 dan membuat pertanyaan kunci peserta didik mendapatkan hasil 70\%. Baca aspek tahapan saat ini yang menjawab pertanyaan dan tuliskan hasil penempatan 70,83 fakta utama yang didapat peserta didik 70,83 . Pada pertemuan kedua aspek yang dinilai tahap pascabaca adalah menulis ringkasan berdasarkan teks laporan hasil penempatan 74.16 dan merevisi ringkasan teks tertulis berdasarkan peserta didik memperoleh 73,33. Berdasarkan hasil disimpulkan bahwa penggunaan strategi PQRST dapat meningkatkan aktivitas dan proses keterampilan membaca siswa kelas enam SDN 029 Sungaipinang.

Kata Kunci: Aktivitas, Proses, Bacaan Intensif, PQRST

\section{A. Pendahuluan}

Membaca pada hakikatnya
adalah suatu yang rumit yang
melibatkan banyak hal, tidak hanya
sekedar melafalkan tulisan, tetapi
berfikir, psikolinguistik dan metakognisi. Sebagian proses visual membaca merupakan proses menerjemahkan simbol tulis (huruf) kedalam kata-kata lisan (Tarigan, 2008:15). Keterampilan membaca dan memahami suatu bacaan sangat penting bagi para penuntut ilmu. Sebagian besar orang memperoleh informasi dan pengetahuan melalui bacaan. Membaca merupakan suatu penelitian, tujuan penelitian dan keterampilan, karena suatu keterampilan maka kemampuan membaca itu bisa dikembangkan dengan banyak berlatih. Keterampilan membaca sudah seharusnya menjadi keterampilan yang perlu dan penting dikuasai oleh semua orang (Dalman, 2013: 12).

Membaca menjadi suatu keterampilan yang dilakukan di SD. Jika peserta didik pada usia sekolah permulaan tidak segera memiliki kemampuan membaca, maka peserta didik akan mengalami banyak ke- 
sulitan dalam mempelajari berbagai bidang studi pada kelas-kelas berikutnya.

Kenyataan yang terjadi di dunia pendidikan Indonesia terutama ditingkat dasar menunjukkan bahwa keterampilan peserta didik yang meliputi baca, tulis, dan hitung masih rendah. Rendahnya kemampuan peserta didik SD dalam tugas kemampuan dasar membaca, menulis, dan berhitung seperti disebutkan tentu terkait dengan berbagai faktor, antara lain: kompetensi guru, sarana pendukung, kurikulum, manajemen sekolah, partisipasi orang tua dan masyarakat, waktu yang tersedia, input instrumental (peserta didik) meliputi inteligensi, tingkat kematangan emosional, serta sikap dan kebiasaan belajarnya, Sandjaja (dalam Yuniawati, 2010).

Kondisi peserta didik saat ini umumnya kurang menyenangi buku, minat baca tidak menonjol, dan mereka lebih suka menonton TV. Membaca dilakukan terbatas pada buku-buku pelajaran pokok yang digunakan di sekolah, itupun bagaikan terpaksa karena akan diadakannya ulangan, atau karena guru memberikan PR. Ketekunan membaca hanya dimiliki beberapa orang peserta didik saja di sekolah. Akibatnya pengetahuan peserta didik sangat terbatas, penguasaan bahasa menjadi lambat bahkan kemampuan menangkap isi bacaan juga rendah. Hal itu harus dijadikan suatu tanda dan peringatan bagi guru dan orang tua, bahwa keterampilan membaca peserta didik harus dipupuk dan dikembangkan.

Pengamatan peneliti dengan guru kelas VI di salah satu SD Negeri, diketahui bahwa tingkat membaca intensif peserta didik masih rendah. Rendahnya kemampuan memahami bacaan peserta didik, terutama pada pembelajaran membaca teks bacaan. Hal ini ditandai oleh peserta didik belum mampu membaca intensif sehingga kesulitan menentukan pikiran pokok tiap paragraf dan ide pokok cerita dalam teks bacaan.

Selain dari permasalahan di atas, terdapat juga permasalahan lain yaitu peserta didik tidak meneliti bagian-bagian tertentu dari keseluruhan tulisan atau buku yang akan dibaca. Tidak dibuat pertanyaanpertanyaan kunci sebagai kunci sebelum membaca. Jarang sekali mencatat fakta-fakta utama pada bahan yang dibaca. Pada setiap akhir 
kegiatan membaca, guru kurang membimbing peserta didik untuk menguji ingatan masing-masing peserta didik tentang bacaan.

Membaca intensif adalah studi seksama, telaah isi, dan penanganan terperinci yang dilaksanakan di dalam kelas terhadap suatu tugas yang pendek kira-kira dua sampai empat halaman setiap hari.

Faktor yang paling besar kontribusinya dalam pencapaian kemampuan membaca di SD antara lain disebabkan oleh penggunaan strategi pembelajaran membaca yang kurang tepat.

Pada penelitian ini, peneliti menggunakan strategi PQRST (preview, question, read, selfrecitation, test). Strategi PQRST adalah untuk mencapai suatu proses pemahaman bacaan secara intensif dan menyeluruh. Selain dari itu, digunakan untuk tujuan menemukan dan menguasai informasi secara detail dan menyeluruh (Ermanto, 2008:91). Strategi PQRST adalah strategi membaca yang terdiri dari lima kegiatan Preview, Question, Read, Summarize, Test serta beberapa kegiatan tambahan terdiri atas membahas pertanyaan dan membahas jawaban. Strategi pembe- lajaran ini mengajak peserta didik untuk mengkonstruksikan pemikirannya sendiri. Langkah-langkah yang tertuang dalam strategi pembelajaran PQRST, memungkinkan peserta didik terlibat dalam pembelajaran yang efektif, seperti pengajuan pertanyaan, menarik kesimpulan, dan latihan yang dapat meningkatkan aktivitas peserta didik dalam kegiatan pembelajaran.

Strategi PQRST memiliki kelebihan dan kelemahan menurut Jayanti (2011) adalah sebagai berikut: mendorong peserta didik untuk belajar lebih aktif saat pembelajaran, peserta didik mampu membaca teks bacaan dengan cermat dan teliti dari awal sampai akhir dengan tujuan untuk menemukan informasi yang ada dalam berdiskusi, peserta didik mampu menemukan informasi yang dibutuhkan dengan cepat, peserta didik mampu mengenali hal-hal yang bersifat asing secara selektif pada bagian-bagian tertentu yang bersifat pokok, peserta didik mampu menjawab pertanyaan tentang informasi yang dibutuhkan dari teks bacaan, guru dapat mengetahui seberapa jauh kemampuan peserta didik dalam memahami isi teks bacaan. Sedangkan kelemahan stra- 
tegi PQRST antara lain: membutuhkan konsentrasi yang penuh dalam memmbaca teks bacaan, membutuhkan tingkat pemahaman yang tinggi, membutuhkan tingkat ketelitian dan kecermatan yang baik.

Dengan menggunakan stra-tegi PQRST, sebanyak apapun buku untuk dibaca akan dapat diatasi. Strategi PQRST ini mempermudah dan mempercepat proses pembacaan serta pengingatan secara efektif. Peserta didik diharapkan dapat meningkatkan keterampilan mem-baca intensifnya.

Berdasarkan uraian di atas, peneliti merumuskan penelitian ini dengan judul "Peningkatan Aktivitas dan Proses Keterampilan Membaca Intensif dengan Strategi PQRST pada Siswa Kelas VI SD".

Secara khusus tujuan penelitian ini adalah untuk mendeskripsikan

1. Peningkatan aktivitas keterampilan membaca intensif dengan menggunakan strategi PQRST di kelas VI SD.

2. Peningkatan proses keterampilan membaca intensif dengan menggunakan strategi PQRST di kelas VI SD.

\section{B. Landasan Teori}

\section{a. Aktivitas Pembelajaran}

Pendidikan tradisional tidak mengenal dan tidak menggunakan asas aktivitas dalam proses pembelajaran. Peserta didik hanya mendengarkan hal-hal yang disampaikan oleh guru. Sistem penuangan lebih mudah pelak-sanaannya bagi guru dan tidak ada masalah atau kesulitan. Guru cukup mempelajari materi dari buku, lalu disampaikan kepada peserta didik, Hamalik (2013:170). Banyak jenis aktivitas yang dapat dilakukan oleh peserta didik di sekolah. Menurut Paul B. Diedrich (dalam Sardiman, 2012:100) kegiatan peserta didik yaitu: visual activities, oral activities, listening activities, writing activities, drawing activities, motor activities, mental activities, emotional activities.

Aktivitas yang digunakan pada penelitian ini adalah visual activities, oral activities, listening activities, writing activities, emotional activities.

\section{b. Membaca}

Membaca merupakan suatu kegiatan atau proses kognitif yang berupaya untuk menemukan berbagai informasi yang terdapat dalam tulisan. Membaca sama dengan membuka jendela dunia 
karena dengan membaca orang dapat mengetahui seisi dunia dan pola berfikir pun akan berkembang. Harjasujana dan Mulyati (dalam Dalman, 2013:6) membaca merupakan perkembangan keterampilan yang bermula dari kata dan berlanjut kepada membaca kritis. Menurut Tarigan (dalam Dalman 2013:7) membaca adalah suatu proses yang dilakukan serta dipergunakan oleh pembaca untuk memperoleh pesan yang hendak disampaikan oleh penulis melalui media kata-kata atau bahasa tulis. Adapun tujuan membaca menurut Tarigan (2008:9) yaitu: membaca untuk menemukan atau mengetahui penemuanpenemuan yang telah dilakukan oleh tokoh, membaca untuk mengetahui mengapa hal itu merupakan topik yang baik dan menarik, membaca untuk menemukan atau mengetahui apa yang terjadi pada setiap bagian cerita, membaca untuk menemukan serta mengetahui mengapa para tokoh merasakan seperti cara mereka itu, apa yang hendak dilihatkan oleh pengarang kepada para pembaca, membaca untuk menemukan serta mengetahui apa-apa yang tidak biasa, tidak wajar mengenai seseorang tokoh, membaca untuk menemukan apakah tokoh berhasil atau hidup dengan ukuran-ukuran tertentu, membaca untuk menemukan bagaimana caranya tokoh berubah.

Membaca mempunyai manfaat. Menurut Saddhono dan Slamet (2012:66) manfaat membaca adalah memperoleh banyak pengalaman hidup, memperoleh pengetahuan umum dan berbagai informasi tertentu yang sangat berguna bagi kehidupan, mengetahui berbagai peristiwa besar dalam peradaban dan kebudayaan suatu bangsa, dapat mengikuti perkembangan ilmu pengetahuan dan teknologi mutakhir di dunia, dapat mengayakan batin, memperluas cakra pandang dan berfikir, meningkatkan tarap hidup dan budaya keluarga, masyarakat, nusa, dan bangsa, dapat memecahkan berbagai masalah kehidupan, dapat menghantarkan seseorang menjadi cerdik pandai, dapat memperkaya perbendaharaan kata, ungkapan, istilah, dan lain-lain yang sangat menunjang keterampilan menyimak, berbicara, dan menulis, mempertinggi potensialitas setiap pribadi dan mempermantap eksistensi dan lain-lain. 
Pembelajaran membaca di sekolah seharusnya menggabungkan kegiatan prabaca, saat baca, dan pascabaca. Membaca memiliki jenisjenis yaitu membaca intensif, membaca kritis, membaca cepat, membaca apresiatif dan estetis, membaca teknik. Pada penelitian ini memfokuskan membaca intensif. Membaca intensif merupakan studi seksama, telaah isi penggunaan terperinci yang dilaksanakan di dalam kelas terhadap suatu tugas pada kegiatan membaca.

Pembelajaran di sekolah harus menggunakan strategi yang cocok agar pelaksanaan pembelajaran sesuai dengan tujuan. Strategi menurut Iskandarwassid dan Sunendar (2011:2) adalah suatu keterampilan mengatur suatu kejadian atau peristiwa. Salah satu strategi pembelajaran yang dinilai tepat untuk digunakan dalam pembelajaran membaca adalah strategi PQRST. Dengan menggunakan strategi PQRST dalam pembelajaran dapat memudahkan dan mempercepat proses pembacaan serta pengingatan secara efektif.

\section{c. Strategi PQRST}

Strategi PQRST juga digunakan untuk memperoleh informasi secara detail dan menyeluruh dari suatu bacaan. Strategi PQRST adalah strategi membaca yang terdiri dari lima kegiatan Preview, Question, Read, Summarize, Test serta beberapa kegiatan tambahan terdiri atas membahas pertanyaan dan membahas jawaban. Strategi PQRST (Preview, Question, Read, Summarize, Test) digunakan untuk tujuan menemukan dan menguasai informasi secara detail dan menyeluruh, Ermanto (2008:91).

Tujuan dari strategi PQRST adalah memudahkan peserta didik untuk memahami isi dari bacaan serta untuk memudahkan dalam mengingat kembali mengenai isi dari bacaan tersebut. Karena strategi ini sangat memudahkan peserta didik yang memiliki kemampuan rendah dalam memahami dan mengingat kembali tentang isi bacaan yang telah dibaca oleh peserta didik, Indrastomo (2014).

Adapun langkah-langkah strategi PQRST terdapat langkahlangkah pembelajaran yang harus ditempuh oleh peserta didik menurut Ermanto (2008:92) yaitu tahapan melakukan tinjauan umum isi buku atau preview, tahapan mengajukan pertanyaan pertanyaan atau question 
tahapan membaca atau read, tahapan meringkas isi bacaan atau summarize, tahapan menjawab pertanyaan atau test.

Peningkatan aktivitas membaca peserta didik terutama untuk membaca intensif dapat ditingkatkan dengan menggunakan strategi PQRST. Strategi PQRST dapat memudahkan dan mempercepat proses membaca dan pengingatan peserta didik terhadap bahan bacaan. Untuk menggunakan strategi PQRST guru harus melakukan beberapa tahapan yaitu: Preview, meninjau bagian-bagian utama dari keseluruhan tulisan yang tujuannya adalah untuk mendapatkan gambaran keseluruhan tentang isi penting pada tulisan itu. Question, buat pertanyaan kunci untuk bagian besar dan kecil dalam tulisan itu sebagai kuncinya. Read, baca satu sub bab ke satu sub bab berikutnya untuk mencari jawaban pertanyaan yang telah dibuat itu. Summarize, catat fakta-fakta utama bab atau bahan yang telah dibaca. Test, menguji diri setelah membaca keseluruhan dan pikirkan ide-ide dari tulisan yang baru anda baca itu yang dapat diingat, Surastina dan Dedi (2011:31).
Harapan penulis strategi ini lebih efektif dalam peningkatan aktivitas dan proses keterampilan membaca intensif peserta didik karena memungkinkan peserta didik terlibat dalam pembelajaran yang efektif.

\section{Metode Penelitian}

Penelitian yang digunakan pada penelitian ini adalah Penelitian Tindakan Kelas (PTK). Menurut Arikunto, dkk (2011:2) PTK adalah sebagai penelitian tindakan yang dilakukan dengan tujuan untuk memperbaiki kualitas proses dan hasil belajar sekelompok peserta didik. menurut Creswell (2011:68) Classroom Action research (rancangan penelitian tindakan kelas) adalah prosedur-prosedur sistematis yang digunakan oleh para guru (atau individu lain dalam setting kependidikan), untuk mengumpulkan data-data kuantitatif dan kualitatif dalam upaya melakukan perbaikan dalam seting kependidikan, kepengajaran, dan pembelajaran peserta didik. Pada beberapa PTK, guru menangani dan mencari solusi terhadap masalah-masalah praktis dan bersifat lokal, seperti isu 
berkenaan dengan disiplin kelas bagi seorang guru.

Penelitian tindakan kelas dilakukan di SD. Subjek penelitian terdiri dari guru kelas VI dan peserta didik kelas VI SD. Adapun penelitian tindakan kelas yang dimaksud dalam penelitian ini, merupakan kegiatan kolaborasi antara peneliti dengan praktisi (para guru/pendidik lain) yang melibatkan peserta didik dalam proses pembelajaran. Apabila guru melakukan PTK untuk kelasnya sendiri, maka ia bertindak selaku peneliti dan sekaligus praktisi, Arikunto (2011:72).

Adapaun data yang digunakan dalam penelitian dikumpulkan dengan menggunakan hasil pengamatan guru dan peserta didik, LKS, catatan lapangan, serta dokumentasi untuk melihat masalah yang ada dalam proses pembelajaran membaca intensif dengan strategi PQRST.

Data yang diperoleh dalam penelitian dianalisis dengan menggunakan data kualitatif yaitu analisis data dimulai dengan menelaah sejak pengumpulan data sampai seluruh data terkumpul. Data tersebut direduksi berdasarkan masalah yang diteliti, diikuti penyajian data dan terakhir penyimpulan. Tahap analisis yang demikian dilakukan berulangulang sampai data selesai dikumpulkan.

\section{Hasil dan Pembahasan}

Berdasarkan hasil pengamatan siklus I dan siklus II, bagaimanakah peningkatan aktivitas keterampilan membaca intensif peserta didik dengan menggunakan strategi PQRST di kelas VI SD. Terlihat peningkatan aktivitas pembelajaran peserta didik sudah mengalami perbaikan. Pembahasan peningkatan aktivitas pembelajaran siklus I sebagai berikut.

Hasil dari lembar pengamatan guru dan peserta didik, terlihat kegiatan yang sudah terlaksana dan kegiatan yang belum terlaksana. Pada lembar pengamatan guru, dapat dilihat ada 16 (40) deskriptor yang muncul. Berarti 16 deskriptor tersebut yang sudah terlaksana pada siklus I. Terdapat 24 (60) deskriptor yang belum terlaksana. Hal ini disebabkan karena guru belum terbiasa menggunakan strategi PQRST pada pembelajaran membaca intensif. Guru kurang paham dengan langkah-langkah strategi PQRST. Sehingga guru belum melaksanakan langkah-langkah 
strategi PQRST secara sistematis. Langkah-langkah strategi PQRST menurut Surastina dan Dedi (2011:31) yaitu meninjau bagian utama dari keseluruhan tulisan, membuat pertanyaan kunci, membaca teks dari satu subbab ke subbab berikut, mencatat fakta-fakta utama, dan tes.

Hasil dari lembar pengamatan peserta didik dapat dilihat bahwa sekitar 24 (60) deskriptor yang muncul. Berarti 24 deskriptor dari pembelajaran yang sudah terlaksana. Ada 16 (40) deskriptor kegiatan yang belum terlaksana. Dari hasil tersebut, terlihat masih rendahnya tingkat pencapaian pada tahapan pembelajaran. Rendahnya tingkat pencapaian pembelajaran tersebut terlihat dari hasil penilaian tahap prabaca, saat baca, dan pascabaca. Hasil ini berdasarkan lembar pengamatan yang diisi langsung oleh observer.

Berdasarkan temuan ter-dahulu, maka guru harus memahami dan melaksanakan langkah-langkah strategi PQRST secara sistematis. Jika guru telah memahami strategi PQRST, diharapkan hasil pembelajaran peserta didik dapat meningkat. Hal ini harus menjadi perhatian guru kelas $\mathrm{VI}$ dan peneliti, agar untuk siklus selanjutnya kegiatan pembelajaran terlaksana dengan baik. Pembahasan peningkatan proses keterampilan membaca intensif siklus I yaitu

Bagaimanakah peningkatan proses keterampilan membaca intensif peserta didik dengan menggunakan strategi PQRST di kelas VI SD.

Pada siklus I, ada enam aspek yang dinilai. Dari enam aspek tersebut, hanya dua aspek yang memperoleh hasil "baik". Sedangkan empat aspek memperoleh hasil “cukup". Menurut Purwanto (2006:27) peserta didik berhasil apabila memperoleh nilai pada rentang 80-100 (sangat baik) dan rentang nilai 70-79 (baik).

Berdasarkan hasil pengamatan, kriteria taraf keberhasilan yang diperoleh sebagian kecil adalah nilai "baik". Sedangkan sebagian besar hasil yang diperoleh adalah "cukup". Hasil yang diharapkan pada penelitian adalah nilai "sangat baik" dan "baik". Maka penelitian dilanjutkan ke siklus II agar hasil yang diperoleh meningkat dari siklus I. Selanjutnya peneliti memberikan masukan kepada guru kelas VI agar 
lebih memahami pelaksanaan pembelajaran membaca intensif dengan strategi PQRST.

Pembahasan pada peningkatan aktivitas pembelajaran dibahas berdasarkan lembar pengamatan guru dan peserta didik pada siklus II. Berdasarkan lembar pengamatan guru, terlihat $37(92,5)$ deskriptor yang muncul. Dari 37 deskriptor, berarti guru sudah melaksanakan pembelajaran dengan baik. Sedangkan yang belum terlaksana ada $3(7,5)$ deskriptor. Hasil siklus II sudah baik dibandingkan dengan siklus I. Peserta didik sudah memperoleh hasil yang hampir sempurna pada kegiatan yang dilaksanakan guru.

Pembahasan pada lembar pengamatan peserta didik, dibahas tentang kegiatan yang sudah terlaksana oleh peserta didik berdasarkan penilaian observer. Berdasarkan lembar pengamatan peserta didik, terlihat ada $35(87,5)$ deskriptor yang muncul. Sedangkan deskriptor yang belum terlaksana ada $5(12,5)$. Hasil yang diperoleh pada siklus II sudah lebih baik karena taraf keberhasilan telah mencapai sangat baik. Hasil dari siklus II meningkat dibanding siklus I.
Berdasarkan temuan terdahulu, guru telah memahami langkahlangkah strategi PQRST yaitu meninjau bagian utama dari keseluruhan tulisan, membuat pertanyaan kunci, membaca teks dari satu subbab ke subbab berikut, mencatat fakta-fakta utama, dan tes. Jika guru telah memahami strategi PQRST, diharapkan hasil pembelajaran peserta didik meningkat. Walaupun masih ada kekurangan, hasil yang diperoleh peserta didik sudah hampir sempurna.

Pembahasan proses keterampilan membaca intensif berdasarkan lembar penilaian yang disiapkan peneliti. Ada tiga tahapan yang dibahas pada pembahasan yaitu prabaca, saat baca, dan pascabaca.

Hasil pembahasan terlihat bahwa perolehan hasil pembelajaran pada setiap tahapan membaca peserta didik. Terdapat enam aspek yang dinilai pada siklus II. Dari lembar penilaian, terlihat keenam aspek memperoleh hasil "baik". Menurut Purwanto (2006:27) peserta didik berhasil apabila memperoleh nilai pada rentang 80-100 (sangat baik) dan rentang nilai 70-79 (baik). 
Berdasarkan hasil penelitian, terlihat taraf keberhasilan yang diperoleh peserta didik berada pada rentang "baik". Hasil tersebut sudah sesuai dengan yang diharapkan. Walaupun belum mencapai taraf keberhasilan sangat baik, tetapi pada siklus II rata-rata yang diperoleh tidak ada pada taraf "cukup" dan "kurang". Maka penelitian cukup sampai pada siklus II. Perbandingan nilai siklus I dan II peningkatan aktivitas dan proses keterampilan membaca intensif dengan strategi PQRST.

Berdasarkan pembahasan terdahulu, terlihat perbandingan hasil pembelajaran membca intensif dengan strategi PQRST. Pada siklus I hanya ada dua aspek yang memperoleh nilai "baik". Sedangkan empat aspek berada pada nilai "cukup". Maka penelitian tersebut berlanjut ke siklus II agar hasil pembelajaran meningkat dari pada siklus I. Hasil pembelajaran pada siklus II, terlihat pada tahapan prabaca aspek satu dan dua memperoleh nilai "baik". Tahapan saat baca pada aspek satu dan dua mempereoleh nilai "baik". Pada tahapan pascabaca aspek satu dan dua memperoleh nilai "baik". Walaupun belum memperoleh nilai "sangat baik", penelitian ini sudah memperoleh hasil baik dan meningkat dari siklus I.

\section{E. Kesimpulan}

Berdasarkan hasil analisis terhadap berbagai data dalam penelitian ini dapat disimpulkan beberapa hal berikut.

Pembelajaran bahasa Indonesia materi membaca intensif dengan menggunakan strategi PQRST dapat meningkatkan aktivitas dan proses keterampilan membaca peserta didik.

Peningkatan pada aktivitas dan proses pembelajaran peserta didik karena guru kelas VI sudah memahami langkah-langkah strategi PQRST. Guru kelas VI telah melaksanakan langkah strategi PQRST secara sistematis sehingga hasil yang diperoleh peserta didik sudah baik.

Berdasarkan kesimpulan dalam penelitian bahwa pembelajaran membaca intensif dengan menggunakan strategi PQRST sesuai dengan kondisi peserta didik di kelas VI SDN 029 Sungaipinang. Pembelajaran membaca intensif dengan menggunakan strategi PQRST dapat meningkatkan aktivitas dan proses keterampilan membaca intensif 
Pendas : Jurnal IImiah Pendidikan Dasar, ISSN Cetak : 2477-2143 ISSN Online : 2548-6950 Volume II Nomor 2, Desember 2017

peserta didik. Dengan demikian berdampak positif pada pembelajaran bahasa Indonesia terutama pada membaca intensif teks laporan pengamatan/kunjungan.

Pembelajaran membaca intensif dengan menggunakan strategi PQRST dapat dijadikan sebagai salah satu alternatif untuk memperbaiki aktivitas dan proses pembelajaran peserta didik. Agar penerapan tersebut memperoleh hasil yang maksimal, hendaknya guru dapat memahami tentang strategi PQRST terlebih dahulu. Dengan memahami strategi PQRST, guru dapat merancang pembelajaran yang mandiri dan aktif bagi peserta didik berdasarkan langkah-langkah yang ada pada strategi PQRST yaitu memprediksi isi bacaan berdasarkan judul, membuat/merumuskan pertanyaan kunci, membaca dari satu subbab ke subbab berikutnya, menjawab pertanyaan yang telah dirumuskan, dan membuat ringkasan.

Berdasarkan pembelajaran yang telah dilaksanakan, peneliti menyarankan agar dapat untuk menunjang keberhasilan pembelajaran bahasa Indonesia dengan menggunakan strategi PQRST, maka diperlukan bahan ajar yang menarik.
Teks bacaan yang disajikan/ digunakan harus kekinian/terbaru agar peserta didik aktif dan tidak bosan. Teks bacaan harus sesuai dengan tingkat pemikiran peserta didik atau isi bacaan yang terdekat dengan lingkungan peserta didik.

Untuk meningkatkan aktivitas dan proses keterampilan membaca intensif, guru berperan sebagai pembimbing dan fasilitator. Oleh karena itu, guru perlu memperhatikan hal penting yaitu memberikan kesempatan dan motivasi kepada peserta didik untuk mengemukakan pendapat atau berbagi ide-ide yang mereka miliki.

\section{DAFTAR PUSTAKA}

Arikunto, Suharsimi. dkk. (2011). Penelitian Tindakan Kelas. Jakarta: PT Bumi Aksara.

Creswell, Jhon W. (2011). Penelitian Kualitatif dalam Bidang Pendidikan. Pekanbaru: UMRI Press.

Dalman. (2013). Keterampilan Membaca. Bandar Lampung: PT Raja Grafindo Persada.

Ermanto. (2008). Keterampilan Membaca Cerdas. Padang: UNP Press.

Hamalik, Oemar. (2013). Kurikulum dan Pembelajaran. Jakarta: Bumi Aksara. 
Iskandarwassid \& Sunendar. (2011).

Strategi Pembelajaran Bahasa.

Bandung: PT Remaja

Rosdakarya.

Purwanto. (2006). Prinsip-prinsip dan

Evaluasi Pembelajaran.

Jakarta:PT. Remaja

Rosdakarya

Saddhono dan Slamet. (2012).

Meningkatkan Keterampilan

Berbahasa Indonesia (Teori dan

Aplikasi). Bandung: Karya Putra

Darwati.

Sardiman. (2012). Interaksi dan

Motivasi Belajar Mengajar.

Jakarta: PT Raja Grafindo

Persada.

Surastina \& Dedi, S.O. Fransisca.

(2011). Teknik Membaca.

Bandar Lampung: Elmatera

Publising.

Tarigan, H.G. (2008). Membaca

Sebagai Suatu Keterampilan Berbahasa. Bandung: Angkasa Bandung.

Jayanti, Tri. (2011). Peningkatan Keterampilan Membaca Intensif dengan Metode PQRST Pada Siswa Kelas VIII C SMP Muhammadiyah I Semarang Tahun Pelajaran 2010/2011.

Diakses: 31 Maret 2014. Semarang: IKIP PGRI.

Yuniawati. (2010). Pelatihan Bermain Kata untuk Meningkatkan Kemampuan Membaca Siswa Kelas I SD di Kabupaten Semarang (Online). Tersedia: http://www.scribd.com/doc/7941 4673/contoh-makalah. Diakses: 01 Maret 2014. 